\title{
Impact of hygienic slaughter practices on Salmonella contamination of broiller carcasses in Biskra, Algeria
}

\author{
N. Guergueb*, N. Alloui, I. Chachoua, A. Ayachi, O. Bennoun and L. Aoun
}

\section{Abstract}

Poultry meat is the primary meat consumed in Algeria, surpassing sheep and beef in the 1980s. However, this product is often at risk of being contaminated by Salmonella. Salmonellosis is a foodborne disease with tens of millions of human cases estimated to occur worldwide, and resulting in more than a hundred thousand deaths per year. According to the World Health Organization, salmonellosis in humans is generally contracted through the consumption of contaminated food of animal origin, including poultry. The main objective of this study was to investigate the risk factors associated with Salmonella contamination of broiler carcasses at the slaughterhouse. Sixty fresh chicken carcasses from six slaughterhouses were subjected to bacteriological analysis in accordance with AFNOR (French Standardization Association) standards. Statistical analyses showed an impact of the hygienic quality of the slaughter process on the likelihood of Salmonella contamination of poultry meat. A correlation $(\mathrm{r}=0.84)$ was found between hygienic slaughter practices and Salmonella contamination of chicken carcasses. The average level of TAMB (total aerobic mesophilic bacteria) was high in carcasses positive for Salmonella ( $\mathrm{t}$-test $=0.019$ ). Not washing live bird transport crates was associated with an increasing risk of Salmonella contamination carcasses (odds ratio/OR $=28$ ). The mean level of TAMB was higher in the presence of the following risk factors: old and small slaughterhouse, not washing live bird transport crates, manual bleeding, scalding type (soaking), non-renewal of scalding water, no disinfectant in water, no ventilation drying, no sanitary facilities. The identification of risk factors responsible for bacterial contamination of broiler meat is essential to determine the most effective methods of prevention.

Key words: chicken meat; odds ratio; risk factors; slaughterhouse

Nadjah GUERGUEB*, DVM, +DVM, Assistant Professor, (Corresponding author, e-mail: g.nadjah@ yahoo.fr), Nadir ALLOUI, DVM, PhD, Ammar AYACHI, DVM, Omar BENNOUN, DVM, Department of Veterinary Medicine, The University Batna, Batna, Algeria; Ilhem CHACHOUA, DVM, PhD, Department of Agricultural Sciences, The University Batna, Batna, Algeria; Laila AOUN, DVM, Department of Veterinary Medicine, Chadli Bendjedid University, El Tarf, Algeria 


\section{Introduction}

Poultry meat is the primary consumed in Algeria, surpassing sheep and beef since the 1980s (FAOSTAT, 2018). However, this product is often at risk of contamination with Salmonella. Salmonellosis is a foodborne disease, caused by the bacteria Salmonella. It is estimated that tens of millions of human cases occur worldwide, resulting in more than a hundred thousand deaths each year. Salmonellosis in humans is generally contracted through the consumption of contaminated food of animal origin, including poultry (WHO, 2013).

The slaughter of poultry is one of the major critical points for hygiene control in the production of poultry meat. During slaughter, cross-contamination may occur, inducing the proliferation of pathogens on initially healthy carcasses (INRA, 2007). Total aerobic mesophilic bacteria (TAMB) is one of the most frequently tests to indicate hygienic slaughter practices, general sanitation, effectiveness of intervention steps and microbiological quality.

The objective of this study was to investigate the risk factors associated with Salmonella contamination of broiler carcasses at the slaughterhouse.

\section{Materials and methods}

This study is a subsequent analysis of existing results from Guergueb et al. (2014) conducted in Biskra in northeast Algeria. The study consisted of a survey to assess the level of compliance with good hygiene practices in modern and traditional poultry slaughterhouses and to evaluate microbiological quality of poultry carcasses intended for human consumption. Statistical analysis was performed to highlight the relationship between bacterial contamination of chicken carcasses and the associated risk factors.

\section{Questionnaire}

A total of six slaughterhouses were visited during the study to inquire about slaughter properties, cleaning and disinfection processes, and hygiene of the slaughterhouse.

\section{Sampling}

Ten carcasses were collected from each slaughterhouse $(n=60)$. Carcasses were sent to the laboratory under positive cold conditions.

\section{Bacteriological analyses}

Each carcass was tested for TAMB, TAMB = TVC, and Salmonella. The analyses were carried out in accordance with AFNOR standards. TAMB was enumerated by creating a 1/10 mother suspension in Tryptone Salt broth (TSB), then performing decimal dilutions up to $10^{5}$ dilution, transfer to plate count agar and incubation for 72 hours at $30^{\circ} \mathrm{C}$ prior to enumeration.

Salmonella testing was carried out in four stages according to ISO 6579: preenrichment, enrichment, biochemical isolation and identification, and finally tested using the API 20E test strip.

\section{Statistical analyses}

Questionnaire results and microbiological tests were subjected to the t-test, ANOVA, and the $x^{2}$ test at $5 \%$ level of significance, depending on the nature of the variables and the number of modality of the questions, to verify the presence of a significant relationship between bacterial contamination of chicken carcasses and the different risk factors studied (hygienic slaughter practices). The correlation (r) was calculated to measure the strength of the relationship between slaughter hygiene indicated by TAMB and Salmonella contamination of chicken carcasses. Odds ratio (OR) at $95 \%$ confidence interval (CI) was calculated to measure the risk of the 
carcasses being contaminated by Salmonella due to certain risk factors. Statistical testing was performed using the SPSS.21 software.

\section{Results}

\section{Salmonella contamination}

The prevalence of Salmonella contamination in broiler slaughterhouses was 83\%; $\sigma=0.41$ (Guergueb et al., 2014). The prevalence of Salmonella contamination in broiler carcasses was $50 \%$, CI 95\% = $0.31-0.69 ; \sigma=0.50$ (Guergueb et al., 2014).

\section{Contamination of broiler carcasses by TAMB}

The box plot (Fig. 1) shows the average level contamination of broiler chicken carcasses by TAMB:

- for carcasses contaminated by Salmonella $\left(\mu=5.27 \log _{10} \mathrm{CFU} / \mathrm{g} ; \sigma=0.45\right)$

- for carcasses not contaminated by Salmonella $\left(\mu=4.73 \log _{10} \mathrm{CFU} / \mathrm{g}\right.$; $\sigma=0.72$ ).

The average level of contamination of broiler chicken carcasses by TAMB was significantly higher in carcasses contaminated by Salmonella, which was confirmed by the t-test.

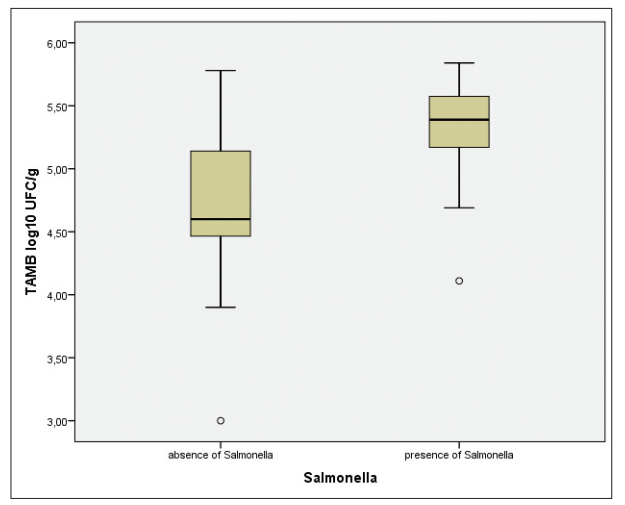

Fig. 1. Relationship between Salmonella and TAMB contamination of carcasses

\section{T-test}

The t-test was employed to compare the average contamination of chicken carcasses by TAMB (as an indicator of hygienic slaughter practices) for carcasses contaminated and not contaminated by Samonella. The t-test value was 0.019 at the confidence level < 0.05, indicating a significant difference between the average TAMB for poultry carcasses contaminated and not contaminated with Salmonella. Therefore, poor slaughter practices are evident in the case of chicken carcasses contaminated with Salmonella.

\section{Correlation}

Knowing that TAMB is a hygiene indicator applied in slaughterhouses, the relationship between hygienic slaughter practices at the slaughterhouse level TAMB and Salmonella contamination of chicken carcasses was measured by the correlation: $r$.

The Correlation coefficient $(\mathrm{r})$ was $0.845(P$-value $=0.034)$. The correlation was significant at $95 \%$, indicating a relationship between hygienic slaughter practices and contamination of broiler carcasses with Salmonella.

\section{Point cloud corresponding to this correlation}

From the point cloud in the scatterplot corresponding to this correlation (Fig. 2), it can be seen that as the average TAMB contamination of chicken carcasses increases, the Salmonella contamination rate of chicken carcasses tends to increase (slaughterhouses 5 and 2) and vice versa. As the average of TAMB contamination decreases, the rate of Salmonella contamination tends to decrease (Slaughterhouse 1).

To complete this comparison, Fig. 3 shows the value of each variable (Salmonella prevalence and average TAMB) for each slaughterhouse examined. 


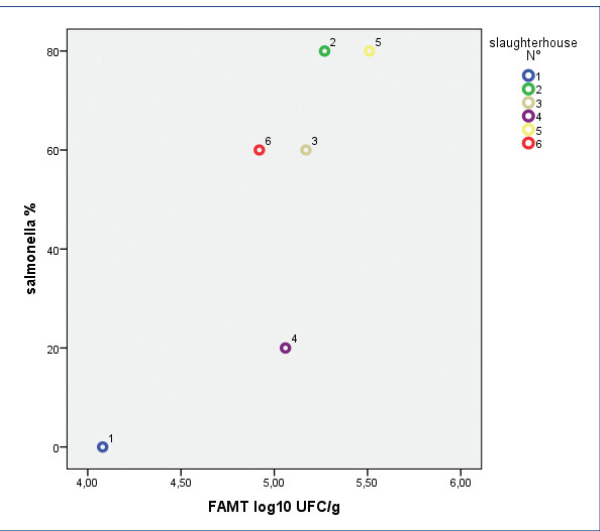

Fig. 2. Correlation between hygienic slaughter practices and Salmonella contamination of carcasses

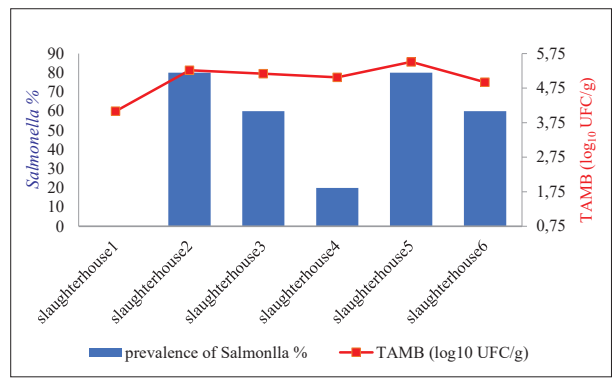

Fig. 3. Relationship between hygienic slaughter practices and the rate of Salmonella contamination of chicken carcasses

\section{Risk factors}

Following our questionnaire, we examined studied certain risk factors related to slaughter properties, cleaning and disinfection processes, and the hygiene of slaughterhouses. The results are outlined below.

\section{Risk factors associated with Salmonella-contaminated carcasses}

To measure the binding strength of risk factors associated with Salmonellacontaminated broiler carcasses, we calculated $x^{2}$ at $5 \%$ level of significance, and we calculated OR to measure the effect of this link.

In this study, we found a significant relationship between Salmonella contamination of chicken meat and the risk factor of washing live bird transport crates, which resulted in a $x^{2}$ value of $11.63(P<0.01)$. The risk of carcasses being contaminated by Salmonella due to not washing live bird transport crates was very high, with $\mathrm{OR}=$ 28 and CI 95\% $=2.82-277.96$ (Table 1).

\section{Risk factors and average TAMB}

The t-test was performed to compare the TAMB averages of carcass

Table 1. Study of risk factors related to Salmonella contamination of chicken carcasses

\begin{tabular}{|l|c|c|c|c|}
\hline Risk factors & $X^{2}$ & P (value) & OR & $\begin{array}{c}\text { Confidence } \\
\text { interval }\end{array}$ \\
\hline Type of slaughterhouse lold and small) & 3.33 & 0.068 & 7 & $0.70-69.49$ \\
\hline No fasting & 0.14 & 0.705 & 1.33 & $0.30-5.91$ \\
\hline Not washing live bird transport crates & 11.63 & 0.001 & 28 & $2.82-277.96$ \\
\hline Bleeding (manual) & 3.33 & 0.068 & 7 & $0.70-69.49$ \\
\hline Scalding type lin tank) & 3.33 & 0.068 & 7 & $0.70-69.49$ \\
\hline Drying (No ventilation) & 3.33 & 0.068 & 7 & $0.70-69.49$ \\
\hline No wenewal of scalding water & 1.43 & 0.23 & 2.67 & $0.52-13.65$ \\
\hline No sanitary facilities & 0.13 & 0.71 & 0.77 & $0.18-3.21$ \\
\hline No disinfectant in water & 3.33 & 0.068 & 7 & $0.70-69.49$ \\
\hline
\end{tabular}


Table 2. Study of risk factors related to the contamination of chicken carcasses by TAMB

\begin{tabular}{|c|c|c|c|c|}
\hline Risk factors & t-test & ANOVA & $\begin{array}{c}P \\
\text { (value) }\end{array}$ & $\begin{array}{c}\text { confidence } \\
\text { interval } \mathrm{Cl} \text { at } 95 \%\end{array}$ \\
\hline Small and old slaughterhouse type & -3.472 & & 0.002 & $1.38730-0.35770$ \\
\hline No fasting & -2.268 & & 0.103 & $0.88785-0.08603$ \\
\hline Not washing live bird transport crates & -2.268 & & 0.031 & $0.98980-0.05030$ \\
\hline Bleeding (manual) & -3.472 & & 0.002 & $1.38730-0.35770$ \\
\hline Scalding type (soaking in tank) & -3.472 & & 0.002 & $1.38730-0.35770$ \\
\hline No disinfectant in water & -3.472 & & 0.002 & $1.38730-0.35770$ \\
\hline No ventilation drying & -3.472 & & 0.002 & $1.38730-0.35770$ \\
\hline No sanitary facilities & -3.472 & & 0.002 & $1.38730-0.35770$ \\
\hline No Renewal of scalding water & & 7.147 & 0.003 & \\
\hline
\end{tabular}

contamination, in the case of presence and absence of certain risk factors. ANOVA test analyses were conducted to calculate the average variance of TAMB with the renewal factor of water scalding which had more than two levels.

The average $\mathrm{TAMB}$, as an indicator of hygienic slaughter practices, was higher in the presence of the following risk factors: old and small slaughterhouse $(P<0.002)$, not washing live bird transport crates $(P<0.05)$, scalding in tank $(P<0.002)$, no disinfectant in water $(P<0.002)$, no ventilation drying $(P<0.002)$, no sanitary facilities $(P<0.002)$, no renewal of water scalding $(P<0.003)$, manual bleeding $(P<0.002)$ (Table 2$)$.

\section{Discussion}

This study allowed us to identify the risk factors responsible for bacterial contamination of chicken carcasses in slaughterhouses and to determine the risk of Salmonella contamination of chicken carcasses associated with certain risk factors.

\section{Prevalence of Salmonella}

We found that the prevalence of Salmonella in fresh broiler meat at slaughter was 50\%. High prevalence rates have also been reported in Belgium 46.6\% (Daube et al., 2002), in Thailand (66\%) (Molla and Mesfin, 2003), in Senegal $43.3 \%$ (Cardinale et al., 2005) and in Algeria 70\% (Djeffal et al., 2010). In European countries, a recent study showed a lower prevalence rate of Salmonella contamination of chicken carcasses (EFSA, 2015) associated with successful EU Salmonella control programmes for reducing the prevalence of the bacteria in poultry populations, particularly in laying hens.

\section{Correlation between Salmonella and the slaughter process}

The relationship between the contamination of carcasses by Salmonella and the level of TAMB contamination is estimated by the correlation $r=0.845$, indicating a strong association between slaughter hygiene practices and contamination of chicken carcasses by Salmonella. This result was confirmed by the t-test $(P<0.019)$. Many authors have reported that the prevalence of Salmonella contamination of broiler carcasses increases after the slaughter process (Carramiñana et al., 1997; Rasschaert et al., 2008). 


\section{TAMB and risk factors}

Several authors have reported a relationship between hygienic slaughter practices and the contamination of chicken carcasses by TAMB (Cohen et al., 2007; Chaiba and Rhazi Filali, 2011; Ruban, 2011). In the present study, the variation in the contamination of chicken carcasses by TAMB was linked to certain risk factors, which was verified by the T-test and ANOVA test.

\section{Transport}

During transport, birds are often stored in stacked open crates, where faeces dropping from an upper crate into a lower crate could cause crosscontamination. There is an additional problem if the crates used are not thoroughly cleaned and disinfected between each collection of birds (WHO, 2002). In this study, we found that not washing live bird transport crates increased the risk of carcass contamination by TAMB $(P<0.03)$. During our visits, we found many slaughterers who have never disinfected or even cleaned their transport crates.

\section{Slaughterhouse type}

The traditional slaughtering process resulted in significantly increased incidences of bacterial flora (Cohen et al., 2007). In this study, the small and old slaughterhouse type increased the risk of contamination of chicken carcasses by TAMB $(P<0.002)$.

\section{Bleeding}

It might be expected that the slaughter knife would introduce microorganisms into the circulatory system and hence the musculature (Mead, 1995). At the slaughterhouses studied, we noticed that workers use knives that are not always disinfected or properly cleaned, and therefore the risk of contamination of chicken carcasses by TAMB associated with manual bleeding is very high $(P<0.002)$.

\section{Scalding}

Scalding by water immersion is more problematic as birds carry large numbers of viable organisms on the skin and feathers and in the faeces, and many of these organisms enter the water as birds are moved continuously through the scald tank (Mead, 1995). The level of contamination of carcasses by TAMB in this study indicates a very high risk of occurrence associated with scalding in the tank $(P<0.002)$. Water may reduce bacterial numbers on the surface of chicken carcasses if the water of scalding tank is continuously replaced with fresh water (Goksoy et al., 2004). In this study, we found no renewal of the water scalding factor which is responsible for increasing the risk of carcass contamination by TAMB $(P<0.003)$.

\section{Disinfection of the water used during the slaughter process}

Washing a carcass (in any form) should decrease the number of bacteria that contaminate carcasses (WHO, 2002; Chaiba and Rhazi Filali, 2011). The addition of chemicals to the scald tank water may reduce the potential for pathogen survival and hence crosscontamination (WHO, 2002). In this review, scalding water without the addition of disinfectant increased the number of bacteria TAMB contaminating carcasses $(P<0.002)$. However, in the slaughterhouses studied, there was an issue concerning the dosage of disinfectant, due to ignorance of the authorized dosage.

\section{Carcass drying by ventilation}

This step inhibits the multiplication of germs retained by the rapid decrease in temperature and water activity on the 
skin's surface (Itavi, 2010). In the present study, the risk factor presented as no ventilation drying was correlated with the increase in the number of TAMB in chicken carcasses $(P<0.002)$.

\section{Salmonella and risk factors}

Many studies have shown that during transport, live bird transport crates promote contact of the excrement of contaminated chicken to the feathers and legs of other chickens (Corry et al., 2002; Marin and Lainez, 2009). Mead (1995) quoted that $46 \%$ of birds from a salmonella-free broiler flock became contaminated during transportation and $99 \%$ of the crates yielded salmonella before the flock was loaded. The stress of transport associated with factors such as vehicle condition, duration of the journey, temperature and road conditions, will increase faecal excretion, thereby increasing the possibility of cross-contamination (ACMSF, 1996). It is essential that cages or crates are properly cleaned and disinfected between different batches of birds (Mead, 1995). In this study, we found a significant relationship between Salmonella contamination of chicken meat and the risk factor of not washing live bird transport crates $\left(x^{2}=\right.$ 11.63 at $5 \%$ level of significance), and the risk of carcasses being contaminated by Salmonella, due to not washing live bird transport crates was very high with $\mathrm{OR}=$ 28 at CI 95\% (Table 1). We also found several slaughterers who have never washed their transport crates.

\section{Conclusions}

The identification of risk factors responsible for bacterial contamination of broiler chicken meat is essential to determine the most effective prevention methods in poultry slaughterhouses, and thus to significantly reduce the level of contamination to provide consumers with meat of excellent quality.
Therefore, continuous improvements of slaughter practices, compliance with good hygiene practices (GHP) at the slaughterhouse level and the application of Hazard Analysis Critical Control Point (HACCP) standards can significantly reduce the rate of Salmonella contamination of chicken carcasses.

\section{References}

1. ACMSF [Advisory Committee on the Microbiological Safety of Food]. 1996. Report on Poultry Meat. London: HMSO.

2. CARRAMIÑANA, J., J. YANGÜELA, D. BLANCO, C. ROTA, A. I. AGUSTIN, A. ARIÑO and A. HERRERA (1997): Salmonella incidence and distribution of serotypes throughout processing in a Spanish poultry slaughterhouse. J. Food Protect. 60, 1312-1317.

3. CARDINALE, E., F. TALL, M. CISSE, E.F. GUEYE, G. SALVAT and G. MEAD (2005): Risk factors associated with Salmonella enterica subsp. enterica contamination of chicken carcases in Senegal. Br. Poult. Sci. 46, 293-299.

4. CHAIBA, A. and F. RHAZI FILALI (2011) Impact des opérations d'abattage dans les tueries traditionnelles sur la qualité bactériologique de la viande de volaille à Meknès (Maroc). Tropicultura 29, 161-167.

5. COHEN, N., H. ENNAJI, B. BOUCHRIF, M. HASSAR, and H. KARIB (2007): Comparative study of microbiological quality of raw poultry meat at various seasons and for different slaughtering processes in Casablanca (Morocco). J. Appl. Poultry Res. 16, 502-508.

6. CORRY, J. E. L., V. M. ALLEN, W. R. HUDSON, M. F. BRESLIN and R. H. DAVIES (2002): Sources of Salmonella on broiler carcasses during transportation and processing: modes of contamination and methods of control. J. Appl. Microbiol. 92, 424-432.

7. DAUBE, G., Y. GHAFIR, J.M. DUMONT, C. GODARD, H. GOOSSENS, J.Y. FRANCOIS and M. CORNELIS (2002): Salmonella prevalence in foods from animal origin in Belgium, period 1997-2001. Septième conférence de microbiologie des aliments, Amphithéâtres de l'Europe, 2002.

8. DJEFFAL, S., L. AOUN, B. MAMACHE and R ELGROUD (2010): Appreciation de la qualité bactériologique des carcasses de poulets de chair frais destinées à la consommation humaine. 1er symposium national des sciences avicoles, 2010.

9. EFSA (2015): The European Union Summary Report on Trends and Sources of Zoonoses, Zoonotic Agents and Food-Borne Outbreaks in 2013. EFSA Journal, no 13. 
10. FAOSTAT (2018): Données de l'alimentation et de l'agriculture. FAO. http://www.fao.org/faostat/fr/.

11. GOKSOY, E. O., S. KIRKAN and F. KOK (2004): Microbiological quality of broiler carcasses during processing in two slaughterhouses in Turkey. Poult. Sci. 83, 1427-1432.

12. GUERGUEB, N., N. ALLOUI, A. AYACHI and O. BENNOUNE (2014): Effect of slaughterhouse hygienic practices on the bacterial contamination of chicken meat. Sci. J. Vet. Adv. 3, 71-76.

13. INRA (2007): A new process to make poultry meat safer. http://www.inra.fr/en/Partnersand-Agribusiness/Results-InnovationsTransfer/All-the-news/A-new-process-tomake-poultry-meat-safer [accessed November $\left.6^{\text {th }} 2019\right]$

14. ITAVI (2010): Abattage et découpe des volailles maigres. Journaux officiels, $113 \mathrm{p}$.

15. MARIN, C. and M. LAINEZ (2009): Salmonella detection in feces during broiler rearing and after live transport to the slaughterhouse. Poult. Sci. 88, 1999-2005.
16. MEAD, G. C. (1995): Hygiene problems and control of process contamination. In: Processing of poultry, pp. 183-220. Springer.

17. MOLLA, B. and A. MESFIN (2003): A survey of Salmonella contamination in chicken carcass and giblets in central Ethiopia. Rev. Méd. Vét. 154, 267-270.

18. RASSCHAERT, G., K. HOUF, C. GODARD, C. WILDEMAUWE, M. PASTUSZCZAK-FRAK and L. DE ZUTTER (2008): Contamination of carcasses with Salmonella during poultry slaughter. J. Food Prot. 71, 146-152.

19. RUBAN, S. W. and N. FAIROZE (2011): Effect of processing conditions on microbiological quality of market poultry meats in Bangalore, India. J. Anim. Vet. Adv. 10, 188-191.

20. WHO [World Health Organization]. (2002): Risk assessments of Salmonella in eggs and broiler chickens. Vol. 2. Food \& Agriculture Org.

21. WHO [World Health Organization]. (2013): Salmonella (non-typhoidal) 2013. https:// www.who.int/fr/news-room/fact-sheets/detail/ Salmonella- (non-typhoidal).

\section{Učinak higijenskih praksi klanja na kontaminaciju trupova brojlera bakterijom roda Salmonella u Biskri, Alžir}

Mr. sc. Nadjah GUERGUEB, dr. med. vet., docentica, dr. sc. Nadir ALLOUI, dr. med. vet., Ammar AYACHI, dr. med. vet., Omar BENNOUN, dr. med. vet., Zavod za veterinarsku medicinu, Univerzitet u Batni, Batna, Alžir; dr. sc. Ilhem CHACHOUA, dr. med. vet., Zavod za poljoprivredne znanosti, Univerzitet u Batni, Batna, Alžir; Laila AOUN, dr. med. vet., Zavod za veterinarsku medicinu, Univerzitet Chadli Bendjedid, El Tarf, Alžir

Meso peradi je meso koje se najviše konzumira u Alžiru, a nadmašilo je ovčetinu i govedinu 1980-ih. Međutim, ovaj proizvod često nosi rizik od kontaminacije salmonelom. Salmoneloza je bolest koja se širi putem hrane, a procjenjuje se da se godišnje jave desetci milijuna slučajeva zaraženih ljudi diljem svijeta, što rezultira s više od stotinu tisuća smrti godišnje. Prema Svjetskoj zdravstvenoj organizaciji, ljudi obično obole od salmoneloze konzumiranjem kontaminirane hrane životinjskog podrijetla, uključujući perad. Glavni cilj ove studije bio je istražiti faktore rizika povezane s kontaminacijom trupova brojlera salmonelom u klaonici. Šezdeset svježih trupova pilića iz šest klaonica podloženo je bakteriološkoj analizi u skladu s AFNOR (francuski Nacionalni institut za norme) standardima. Statističke analize pokazale su učinak kvalitete higijene $\mathrm{u}$ postupku klanja na vjerojatnost kontaminacije mesa peradi salmonelom.
Ustvrđena je povezanost $(\mathrm{r}=0,84)$ između higijenskih praksi klanja i kontaminacije trupova pilića salmonelom. Prosječna razina TAMB (broja aerobnih mezofilnih bakterija) $\mathrm{u}$ trupova pozitivnih na salmonelu ( $\mathrm{t}$-test $=0,019)$ bila je visoka. Propuštanje pranja sanduka za prijevoz živih ptica povezano je s povećanim rizikom od kontaminacije trupova salmonelom (omjer vjerojatnosti/OV=28). Srednja razina TAMB bila je viša u prisutnosti sljedećih faktora rizika: stare i male klaonice, propuštanje pranja sanduka za prijevoz živih ptica, ručno puštanje krvi, vrsta parenja (namakanje), ne mijenjanje vode za parenje, izostanak dezinfekcijskog sredstva u vodi, sušenje bez ventilacije, izostanak sanitarija. Identifikacija faktora rizika odgovornih za kontaminaciju mesa brojlera bakterijama bitna je za određivanje najučinkovitijih metoda prevencije.

Ključne riječi: piletina, omjer vjerojatnosti, faktori rizika, klaonica 